\title{
Contracts and Returns in Private Equity Investments
}

\author{
${\text { Stefano } \text { Caselli }^{a}, \text { Emilia Garcia-Appendini }^{b, \ddagger}, \text { Filippo Ippolito }}^{c, *}$ \\ ${ }^{a}$ Universitá Commerciale Luigi Bocconi, Italy \\ ${ }^{b}$ Universitá Commerciale Luigi Bocconi \& IGIER, Italy \\ ${ }^{c}$ Universitat Pompeu Fabra \& Barcelona Graduate School of Economics, Spain
}

\begin{abstract}
We analyze the relationship between contracts and returns in private equity (PE) investments. Contractual control in the form of covenants tends to be employed to identify good deals. Better quality firms are more likely to have covenant-rich contracts, as they are less concerned by the constraints imposed by the covenants. PE investors appoint closer associates of the fund in deals that are performing poorly but tend to outsource board governance in better deals. Collectively, our evidence suggests that PE investors operate along two dimensions, choosing covenants and board seats differently, based on the ex-ante quality of the company.
\end{abstract}

JEL Classification: G11, G23, G24

Keywords: private equity funds; venture capital; IRR; covenants; board directors

† Present address: University of St. Gallen, Rosenbergstrasse 52, 9000 Switzerland.

* Corresponding author at: Department of Economics and Business, Universitat Pompeu Fabra, Ramon Trias Fargas, 25-27, 08005 Barcelona, Spain. Tel. (+34) 93542 2578. Fax. (+34) 935421746. Email address: filippo.ippolito@upf.edu 


\section{Introduction}

In recent years, the uniqueness and complexity of private equity (PE) contracts has attracted much interest among academics and the wider public. From a practical perspective, this has been the result of the increasing importance of PE in the economy. From a conceptual perspective, PE contracts have offered academics a primary exploratory field for developing and testing theories of optimal contracting. An extensive theoretical literature has developed on how to optimally design the investments of PE investors in venture capital financed firms. ${ }^{1}$ From the empirical viewpoint, however, there is still relatively little evidence on the relationship between contract design and investment returns. ${ }^{2}$

In this paper, we begin to fill this gap in the literature by examining how contracts and returns are related in PE investments. There are many dimensions along which PE investors structure the terms of an investment in a PE-financed firm. These include, among others, the choice of securities, voting and cash flow rights, liquidation options, and the appointment of directors in the board of the target firm. In most cases, the definition of these terms is expressed in specific covenants that $\mathrm{PE}$ investors include in the contract at the time of entry.

The covenants used by PE investors are rather different from those attached to bank loans (Drucker and Puri, 2009) or credit lines (Sufi, 2009) which primarily focus on the maintenance of certain financial ratios, such as cash flows over assets or interest coverage. In contrast, covenants in a PE context effectively define the securities held by PE investors, as they identify the contingencies in which certain actions can be taken by the involved

\footnotetext{
${ }^{1}$ The theoretical models presented in Casamatta (2003), Cornelli and Yosha (2003), Hellmann (1998, 2006), Schmidt (2003) offer different explanations for the complex contracting solutions commonly employed in venture capital investments (Kaplan and Strömberg, 2002, 2004; Sahlman, 1990).

${ }^{2}$ Cumming (2008) is the first to provide a systematic analysis of the relationship between contractual characteristics and performance of PE investments. He does so by relating the allocation of control rights in PE contracts to the likelihood of exiting via an acquisition, a write-off, or an IPO.
} 
parties. By focusing on covenants we are then able to offer new insights on the structure of PE contracts and their relation to returns.

We base our work on a proprietary database of 834 deals provided by a currently active Italian management company. The database covers all deals that occurred between January 1999 and December 2005 in which the target company is incorporated in Italy and the investment company is registered as an Italian PE management company. Although our sample is restricted to Italian deals, it is informative of the PE market in continental Europe due to the common regulatory framework shared by the members of the European Union. The majority of our deals belong to the categories of expansion financing $(50.7 \%)$ and buyouts $(27.1 \%)$, while venture capital financing, in the form of early stage, represents only a minority of observations (16.7\%). Exit from investment primarily occurs via trade sale $(86.9 \%)$, while IPOs and write-offs are relatively rare (respectively $5.1 \%$ and $6.5 \%$ ).

We begin our analysis by observing that covenant-heavy contracts are generally associated with higher returns, regardless of whether the measure of returns employed is the IRR of the fund, the change in ROE and ROA, or the increase in sales over the investment period. The relationship seems to be driven by lockups, permitted-transfer rights, exit ratchets, and, to a lesser extent, rights of first refusal and redemption rights.

We then examine self-selection in the choice of covenants. Li and Prabhala (2007) review several methods of self-selection. We focus on the model of Lee (1978), subsequently implemented by Goyal (2005) in a finance context. ${ }^{3}$ In this model the selection decision depends on the expected treatment effects that the inclusion of covenants has on returns. For completeness, we also estimate a standard switching model. From the results obtained in the estimation of the two models, we find that there is a selection effect associated with

\footnotetext{
${ }^{3}$ Dunbar (1995), Fang (2005), Goyal (2005) and Song (2004) all provide examples of how self-selection can be employed to study the role of private information in relation to the choices of economic agents. See Lee and Prabhala (2007) for a survey.
} 
the inclusion of covenants, and that covenant heavy firms are generally better performers.

These findings are consistent with two explanations. First, it may be that firms with higher expected performance have lower bargaining power vis-a-vis PE investors and are required to accept more covenants. Alternatively, firms with better prospects are willing to take up more covenants because they are less likely to be constrained by them. Therefore, the presence of covenants acts as a signal of high quality. The first of these two explanations does not seem very plausible, as firms with better prospects should have stronger rather then weaker bargaining power when dealing with a PE investor. The second explanation appears relatively more plausible and particularly well suited to covenants that offer protection to PE investors if performance is lower than expected. These covenants include redemption rights and permitted transfers, and are unlikely to bind for a successful firm. The estimated treatment effects are stronger for covenants that provide incentives to managers for profit maximization, such as deals with lockup, rights of refusal, or an exit ratchet.

Next, we examine the choice of directors appointed in the board of target firms, which we regard as an alternative contracting dimension through which PE investors control the behavior of the firms they invest in. We classify appointed directors as either outsiders or insiders. We employ four different measures for this classification. We look at whether the appointed director is or has been an employee of the PE fund, presently has strong ties with the fund, had strong ties with the fund in the past, and whether there is a match in the maturity of the appointment and the duration of the fund. We borrow from Lerner (1995) the hypothesis that insiders are appointed when the need for oversight is greater, which suggests a negative relationship between investment performance and the strength of the ties between appointed director and fund. Our findings show a negative association between the appointment of insiders and target firm profitability, which suggests that insiders are 
appointed in firms with lower prospects, thus providing support to Lerner's hypothesis.

Overall, our findings contribute to the understanding of how PE investors design contracts in the presence of hidden information and moral hazard. They operate along two dimensions choosing covenants and board seat differently, based on the ex-ante quality of the company. Contractual control in the form of covenants is primarily employed to identify good deals. Firms signal their quality by accepting more or less covenant-heavy contracts, as better firms are less concerned by the constraints imposed by the covenants. At the same time, however, covenants can also change performance, possibly by strengthening the incentives of firm managers towards profit maximization. In addition to covenants, PE investors employ direct board control to strengthen control in worse deals. They do so by appointing closer associates of the fund in deals that are performing poorly and outsourcing board governance in better deals.

To our knowledge this is the first paper that addresses empirically the relationship between contracts and returns in PE investments. It establishes a link between the strand of literature on the returns of PE investments (Bygrave and Timmons, 1992; Gompers and Lerner, 1997; Groh and Gottschalg, 2006; Kaplan and Schoar, 2005; Lerner et al., 2007; Ljungqvist and Richardson, 2003) and that on venture capital contracts (Bengtsson, 2010; Gompers, 1999; Lerner and Merges, 1998; Metrick and Yasuda, 2010).

The rest of the paper is organized as follows. Section 2 describes the data collection process and provides descriptive statistics for our sample. Section 3 provides a discussion of the information content of covenants. Sections 4 and 5 examine the relation between covenants and returns using selection models. Section 6 analyzes the choice of board directors. Finally, Section 7 concludes. 


\section{Data Collection and Sample Description}

We use a proprietary database provided by MPS Venture SGR, a currently active Italian management company. The database covers all deals that satisfy the following requirements: 1) investment occurred between January, $1^{\text {st }} 1999$ and December, $31^{\text {st }} 2005$; 2) target company is incorporated in Italy; 3) investment company is registered as an Italian PE management company.

Data were collected by MPS Venture SGR from several sources: 1) the Bank of Italy provided the list of Italian PE management companies and the aggregate number of deals that these companies have made; $\left.{ }^{4} 2\right)$ the Italian Private Equity and Venture Capital Association (AIFI) provided information for single deals, including: target firm name, type and size of investment, percentage of shares acquired by the fund, entry and exit dates, exit, leverage, IRR, and covenants; 3) private interviews held by MPS Venture SGR with other fund managers completed the information of AIFI; 4) Bureau Van Dijk's AIDA/Amadeus Database, and Italian Balance Sheet Central Database (Centrale dei Bilanci), provided balance sheet data; 5) the Italian Credit Bureau (Centrale dei Rischi) provided information about credit relationships; and 6) the Trade Ministry (Camera di Commercio) and the Italian Security and Exchange Commission (Consob) provided information on board members.

Importantly, due to privacy restrictions, MPS Venture SGR has not disclosed the names of any of the entities involved. Therefore, 1) we are unable to merge our data back into publicly available databases such as Amadeus/AIDA to complement the balance sheet information that may still be missing; 2) we cannot distinguish between first, second or higher rounds of financing to the same firm by different PE investors; and 3) we do

\footnotetext{
${ }^{4}$ According to the European 1998 Financial Services Directive, PE management companies are regarded as regulated financial companies; as such, they must register with the Central Bank of their country of incorporation, and must disclose the aggregate number of deals made by each fund.
} 
not know which firms are public or private at the time of investment. Nevertheless, in our sample, the standard investment strategy for PE funds is "one firm, one investment", meaning that neither stage financing nor syndication are employed.

Finally, we complement the database of MPS Venture with aggregate macroeconomic data at the time of investment, obtained from Datastream and AIDA/Amadeus: 1) the returns of the Italian stock index, 2) the ratio of IPOs over newly created firms, 3) industry leverage, and 4) industry ROE.

\subsection{Sample Characteristics}

The sample includes 834 investments made by 104 PE funds owned by 73 management companies. Most target firms operate in the consumer goods sector (34\%), the general industrial sector (25\%), and the services sector (20\%). Consistent with the structure of the Italian corporate sector, most target firms are majority owned by individuals or families $(69.28 \%)$.

All investments were financed between 1999 and 2005, with 2000, 2001 and 2004 being peak years. The median investment size is 4.1 million euros. The median annualized IRR ranges from $-4.33 \%$ to $49.31 \%$. Returns peak during the technology bubble of 1999 2001, and are low after the financial crisis in 2011. The majority of our deals consist of expansion financing (50.7\%), followed by buyouts $(27.1 \%)$, early stage $(16.7 \%)$ and turnaround (5.39\%). Early stage and expansions are much smaller than buyouts and turnarounds. Buyouts include most of the larger deals in our sample, which however look small by international standards, particularly if compared to the large buyouts recently witnessed in the US and the UK (see Axelson et al., 2012).

All but 11 deals are exited by the time of data collection (May 2011). Trade sale is the most common form of exit (86.9\%). Most exits occurred between 2002 and 2008 (731 
deals). IPOs and write-offs are less frequent and account for $5.1 \%$ and $6.5 \%$ of the sample, respectively. IPOs are more correlated with buyouts and expansions than with early-stage and turnarounds. In our sample $60.74 \%$ of the management companies are controlled by a banking group. These management companies count for $62.35 \%$ of the deals in the sample. Within this subsample the controlling bank has a credit relationship with the target firm in $80.38 \%$ of cases. Importantly, the existence of a credit relationship is evaluated at the time of investment and is not related to debt issued in conjunction with a leveraged buyout, a type of deal that is very rare in our sample. These data on credit relationships suggest that equity financing by a PE fund in conjunction with debt financing by the controlling bank is a common phenomenon in Italian deals.

\section{TABLE 1 ABOUT HERE}

Table 1 provides descriptive statistics of our returns measures, which include yearly IRR, and the yearly changes in sales, ROA, and ROE over the investment period. IRR is simply computed as the difference in PE investors' equity stake at the time of investment and exit. Annualizations are based on yearly compounding. ${ }^{5}$ These measures respectively proxy for the returns to the PE investors (IRR), to all stakeholders in the firm (sales, ROA) and to equityholders (ROE). The averages (medians) of yearly IRR, growth in sales, ROA and ROE are $9.4 \%(10.61 \%), 6.68 \%(3.92 \%), 6.01 \%(3.19 \%)$, and $17.59 \%(7.23 \%)$. The estimated median IRR for the 11 unexited deals is $-4.32 \%$. As comparison Kaplan and Schoar (2005) find that equal-weighted median and average IRRs reported by Venture Economics over the period 1980-2001 are 12\% and 17\%, respectively. Cochrane (2005) finds that venture capital investments generate average log returns of $15 \%$ per year. Bygrave

\footnotetext{
${ }^{5}$ For the 11 un-exited deals in the sample, IRR is estimated on the basis of the change in net asset value during the investment period.
} 
and Timmons (1992) find an average IRR of $13.5 \%$ for the period 1974-1989. Gompers and Lerner (1997) report an arithmetic average yearly IRR of $30.5 \%$ gross of fees over the years 1972-1997. Ljungqvist and Richardson (2003) produce an estimated IRR of 19.8\%. Finally, we observe that buyouts and early-stage are respectively the most and the least profitable type of investments, irrespective of the measure employed. Kaplan and Schoar also find that returns to buyout funds are slightly higher than the returns to venture funds. In our sample, IPOs are the most profitable type of exit.

\section{TABLE 2 ABOUT HERE}

\section{Covenants}

In our sample we observe seven different covenants: lockups, permitted-transfer rights, redemption rights, tag-along rights, drag-along rights, rights of first-refusal, and exit ratchets. A definition of these covenants is provided in Table 2. We find that in our sample there is more variety in the choice of covenants than in previous studies. Cumming (2008) reports four covenants: right to replace the CEO, redemption rights, drag-along rights, and antidilution rights. Kaplan and Strömberg (2002) report the use of redemption rights, anti-dilution provisions, and automatic-conversion provisions. In both papers PE investors employ a mix of securities which includes various types of preferred stock and convertible debt, while in our sample PE investors always hold common equity.

Table 3 provides descriptive statistics for our set of covenants. Tag-along rights are the most common type of covenant (86.93\% of the deals), followed by drag-along rights, permitted transfer and redemption rights. There is relatively little variation in the use of covenants across different investment types, but there is large variation across different types of exit. Lockups, permitted transfers, redemption rights, rights of first-refusal and 
exit ratchets are more likely to be included when exit occurs via an IPO. In untabulated results we find that over time there has been a tendency towards "covenant-lite" contracts, with a marked reduction in the use of tag-along, drag-along and redemption rights.

\section{TABLE 3 ABOUT HERE}

We find a positive correlation in the use of lockups, permitted transfers, redemption rights and rights of first-refusal. This suggests that certain types of covenants might be bundled together to form a contracting style. To explore this point in more detail and identify different contracting styles, we perform a multiple correspondence analysis (MCA). ${ }^{6}$ As in Principal Component Analysis, the MCA offers a low-dimensional representation of the data, in a way that best preserves the original variance of the data. The first dimension of variation explains $84.2 \%$ of covenant variability. This component is strongly related to lockups and rights of first-refusal, and to a smaller extent also to permitted transfers, redemption rights, and exit ratchets. The second component explains only $0.03 \%$ of the total data variability and is strongly related tag-along rights and to drag-along rights. We observe three relatively well defined clusters, plus a singleton. Lockups and rights of first-refusal represent the first cluster. The second cluster is composed by tag-along and drag-along rights. We label this cluster default covenants because tag- and drag-along rights are present in the majority of deals. Redemption rights and permitted-transfer rights form the third cluster. Since both give PE investors an exit option, we refer to this cluster as protection covenants. Exit ratchets represent a singleton which cannot be perfectly mapped into any of the previous clusters. Given that exit ratchets are instrumental in providing incentives to managers, we group them together with lockups and rights of first refusal to form the third group of covenants to which we refer as incentive covenants. In

\footnotetext{
${ }^{6}$ For an overview of MCA methodology see Johnson and Wichern (2007), Chapter 12.
} 
Table 3 we report statistics for the three clusters.

\subsection{The Information Content of Contracts}

The existing theories on the role of contracts in the financing of an entrepreneurial firm identify adverse-selection and double-sided moral hazard as the two main sources of information problems in venture capital contracts. ${ }^{7}$ We examine from a theoretical standpoint the interplay between covenants, information problems and returns.

We start by looking at incentive covenants. These covenants provide incentives to managers for maximizing firm value, and also appear to be associated with high quality firms. Aghion et al. (2004), Brav and Gompers (2003), Casares-Field and Hanka (2001), and in a broader setting Holmström (1979), suggest that lockups help align the incentives of managers and PE investors with the maximization of equity value. Also, lockups signal firm quality because they are generally associated with IPOs (see Table 3) which is the most profitable type of exit. Rights of first-refusal (a.k.a as preemption rights) and exit ratchets are also meant to preserve the incentives of managers towards value maximization, respectively by preventing a dilution of the managers' interest in the firm, and by rewarding managers with new shares in case of high returns. ${ }^{8}$ Overall, we should expect incentive covenants to be positively correlated with returns because they signal high firm quality and strengthen incentives.

With respect to protection covenants, permitted-transfer rights give $\mathrm{PE}$ investors the option to sell their stake in the firm without requesting the permission of other shareholders (Yates and Hinchliffe, 2010), while redemption rights allow PE investors to sell their shares

\footnotetext{
${ }^{7}$ See Aghion and Bolton (1992), Bascha and Walz (2001), Casamatta (2003), Cornelli and Yosha (2003), Dessi (2005), Hellmann (1998, 2006), Inderst and Mueller (2004), Renucci (2000), Repullo and Suarez (2004), Schmidt (2003).

${ }^{8}$ Two special types of exit ratchets employed in the U.S. are returns and time vesting (Kaplan and Strömberg (2002)).
} 
back to the company (long put), typically in the event an IPO or a public merger becomes unlikely. Both types of covenants signal strong bargaining power of PE investors, but also indicate uncertainty about the firm's future prospects.

Finally, the two default covenants, tag-and drag-along rights, maximize the likelihood of a profitable exit and should then correlate positively with returns. Empirically it is difficult to estimate their relationship with returns, precisely because the vast majority of firms in the sample includes one of these covenants, thus reducing the power of the statistical tests.

\section{The Correlation between Covenants and Returns}

In this section we analyze the correlation between the use of covenants and investment returns. We start our analysis by observing the unconditional pairwise correlation between our returns measures and covenants. Following Drucker and Puri (2009), we also aggregate the covenants into an index, covenant index, which equals the number of covenants employed in a deal and is meant to proxy for the restrictiveness of the contract. We find that lockups, permitted transfers, first refusal, exit ratchet and the covenant index are positively and (almost always) significantly correlated with returns. Redemption rights are positively and significantly correlated with IRR and IPO, while they are not significantly correlated with the other measures. Tag-along and drag-along rights are generally uncorrelated with returns.

Next, in Table 4 we compare the univariate differences in return measures between deals with and without each type of covenant, using t-tests and non-parametric Wilcoxon tests for differences on means. Due to space restrictions, we choose yearly IRR and yearly change in sales as reference return measures. Panel A shows that yearly IRR is always higher for deals containing any type of covenant $(X=1)$ than for those without $(X=0)$. 
Similar but weaker results hold for yearly change in sales as reported in Panel B. In both panels we also include our three contracting styles. Incentive covenants is a dummy for the inclusion of either a lockup, right of first refusal or exit ratchet. Protection covenants is a dummy for presence of either a permitted transfer or a redemption right. Default covenants is a dummy for presence of either tag- or drag-along rights. We find that only incentive covenants yield a high and significant difference.

\section{TABLE 4 ABOUT HERE}

\subsection{Multivariate Evidence}

We next explore the relationship between covenants and returns in a multivariate setting controlling for firm and deal characteristics, and monitoring. We consider the following firm characteristics: profitability, size, leverage, and industry (nine dummies for the sector in which the target firm operates). The investment characteristics include: the percentage of shares acquired, investment type (dummies for early, expansion, buyout and turnaround), vintage (dummies for the year of the investment), investment duration (length of the investment expressed in months), bank relationships (a dummy that takes value of one if the fund is majority owned by a bank and there is a lending relationship between bank and target firm). We include a dummy for un-exited deals. We also control for the cumulative number of board seats simultaneously held by the director appointed by the fund. As we

discuss in more detail in Section 6 below, a higher number of board seats proxies for a closer relationship between the director and the fund. These variables are defined and summarized in Table 5.

\section{TABLE 5 ABOUT HERE}


We run a set of 66 regressions, one for each return measure (plus IPO and Write-off) on each covenant (plus the covenant index and the three contracting styles), controlling for the above firm and deal characteristics and for board seats. We use OLS to estimate all equations involving a continuous measure of returns, and probit models to estimate the probability of exit. We cluster the standard errors at the PE investor level. ${ }^{9}$

The results of all the regressions performed above are summarized in Table 6. Panel A contains the complete model specifications for the regressions of each returns measure on the covenant index. In Panel B we run the same specifications as in Panel A with each single covenant separately. We also run three specifications, one for each contracting style (incentives, protection, default). To be concise, in Panel B we report only the estimated coefficients of the relevant covenant for each regression. The estimated (untabulated) coefficients of the control variables in Panel B are qualitatively very similar to their counterparts reported in Panel A.

The main findings of Table 6 are: 1) the relationship between the covenant index and returns is strong and positive also in a multivariate setting; 2) this relationship appears to be driven mainly by lockups, permitted transfers, and exit ratchets, and to a lesser extent by rights of first refusal and redemption rights; 3) tag- and drag-along appear generally uncorrelated to returns, thus confirming their status of default covenants.

\section{TABLE 6 ABOUT HERE}

\subsection{Selection Models}

The empirical findings of the previous section raise non-trivial theoretical and empirical issues. From a theoretical standpoint, in a model of optimum contracting in which covenants

\footnotetext{
${ }^{9}$ In untabulated results we carry out a robustness check by including PE fixed effects (a dummy for each management company) in the regressions. Results on covenants are unaffected.
} 
are chosen to maximize returns, a reduced form equation of returns should depend solely on the parameters of the model. The same should hold for covenants. ${ }^{10}$ If we take this line of reasoning literally, then empirically we should not expect to observe a relationship between covenants and returns. However, in practice such relationship may arise because covenants can proxy for omitted variables. As suggested by Li and Prabhala (2007), we may regard this as a problem of self-selection in which covenants capture some of the information privately held by the contracting parties. The selection of covenants gives us information about some unobserved heterogeneity in firm quality.

Self-selection, however, may not be the only reason why covenants are interesting from an empirical point of view. For instance, covenants can also change manager behavior by improving incentives to maximize firm value. This would imply a positive relationship between covenants and returns, which could also partially explain the empirical facts observed in Table 6. We employ the methods suggested by Lee (1978) to estimate selection and treatment effects of covenants on returns.

\section{Estimates of Self-Selection Models}

We model the decision to include covenants in the PE contract with the following equation:

$$
C_{i}=\gamma\left(y_{1 i}-y_{0 i}\right)+Z_{i}^{\prime} \xi-u_{i}
$$

\footnotetext{
${ }^{10}$ In principle, returns and covenants should not be related at the optimum. To illustrate why, consider a simple theoretical model in which $y(C, X)$ is a measure of firm returns, which depends on the choice of covenants to be included in the contract, $C$, and a set of exogenous parameters, $X$. If we assume that contracts are chosen optimally to maximize returns and that $y$ is concave, then the optimal contract must satisfy the first order condition $\partial y / \partial C=0$. This implies that the optimal choice function $C^{*}(X)$ depends only on $X$. As a consequence, the optimal value of $y$ is $y^{*}\left(C^{*}(X), X\right)=y^{*}(X)$. In other words, at the optimum returns should not depend on $C$. $X$ determines both the choice of covenants $C^{*}$ and returns $y^{*}$. We thank an anonymous referee for suggesting this argument.
} 
Here $C_{i}$ represents the value of including covenants in the contract, i.e. covenants will be included if $C_{i} \geq 0$, and they will not be included otherwise. $y_{1 i}$ is the return of an investment with covenants, and $y_{0 i}$ is the return on an investment without covenants; thus, $\left(y_{1 i}-y_{0 i}\right)$ is the increase in performance when covenants are included in the contract, relative to when they are not included. $Z_{i}$ contains other variables that may affect the choice of introducing covenants, such as firm and fund-specific characteristics, and market conditions at the time of the investment.

Performance is different when covenants are included than when they are not. Thus, we model these two cases separately as a function of a vector $X_{i}$ containing only firm and fund characteristics:

$$
\begin{aligned}
& y_{1 i}=X_{i}^{\prime} \beta_{1}+u_{1 i}, \\
& y_{0 i}=X_{i}^{\prime} \beta_{0}+u_{0 i} .
\end{aligned}
$$

Equation (2) is the outcome regression for investments with covenants and Equation (3) is the outcome regression for investments without covenants. This means that only one of $y_{1 i}$ or $y_{0 i}$ is observed for each individual $i$, depending on whether $C_{i} \geq 0$ or $C_{i}<0$. We define a dummy variable $I_{i}=1$ when $C_{i} \geq 0$ and $I_{i}=0$ when $C_{i}<0$. As Li and Prabhala (2007) point out, the above set-up is a generalization of the standard switching model discussed in Maddala (1983). The standard model also considers two regimes, as in Equations 2 and 3. The difference is that the decision to include covenants is given by the criterion function

$$
C_{i}=Z_{i}^{\prime} \xi-u_{i}
$$

which does not depend on $y_{1 i}$ or $y_{0 i}$.

The procedure developed by Lee (1978) to estimate the system of equations (5), (2) and (3) consists of substituting the outcome Equations (2) and (3) into the selection 
Equation (1). This allows us to obtain a reduced-form model in which covenants are solely a function of firm-deal characteristics and market conditions:

$$
C_{i}=Z_{i}^{* \prime} \xi^{*}-u_{i}^{*}
$$

As a second step, Equation (5) is estimated using a probit model with maximum likelihood, and the linear predictions, $Z_{i}^{* \prime} \widehat{\xi}^{*}$ are used to calculate the inverse Mills ratios, $\lambda_{1 i}=$ $-\phi\left(Z_{i}^{*} \widehat{\xi}^{*}\right) / \Phi\left(Z_{i}^{*} \widehat{\xi}^{*}\right)$ and $\lambda_{0 i}=\phi\left(Z_{i}^{* \prime} \widehat{\xi^{*}}\right) /\left(1-\Phi\left(Z_{i}^{* \prime} \widehat{\xi^{*}}\right)\right)$. Consistent estimates of $\beta_{1}$ and $\beta_{0}$ are then obtained by augmenting Equations (2) and (3) with the inverse Mills ratio as additional right-hand side variables, and estimating the equation with OLS. Finally, as third step we substitute the difference in expected performance for the whole sample, $\widehat{y}_{1 i}-\widehat{y}_{0 i}$, into the selection Equation (1), and produce consistent estimates of the structural probit model parameters $\gamma$ and $\xi^{11}$

The selection-adjustment estimation procedure sketched here is useful for the following reasons: 1) by adjusting for self-selection we obtain consistent estimates for $\beta_{1}$ and $\beta_{0}$; 2) the statistical significance of the coefficient for the inverse Mills ratio captures possible self-selection effects associated with the inclusion of covenants; and 3) the statistical significance of parameter $\gamma$ captures possible treatment effects associated with the inclusion of covenants. The omitted variables used to correct for self-selection, $\lambda_{1 i}$ and $\lambda_{0 i}$, can be interpreted as an estimate of the private information underlying a firm's choice (Li and Prabhala, 2007).

It is worth noting that in a standard switching model, a positive sign for the coefficient of the inverse Mills ratio means that covenants act as a signal of high returns, and it implies

\footnotetext{
${ }^{11}$ The selection equation contains the (unobserved) difference in ex-ante expected returns between deals with and without covenants. We proxy for the ex-ante expected returns using the ex-post (observed) realized outcomes. The same approach is employed in Lee (1978), where ex-post observed wages are used in the criterion function that determines whether workers should unionize or not.
} 
a positive covariance between the unexplained factors that affect returns and those that affect the choice of covenants. In the Lee (1978) model, however, the signs of the coefficients for the inverse Mills ratios do not have a direct interpretation, because the coefficients estimate the covariance between $u_{1 i}$ and $u_{i}^{*}$ (or $u_{0 i}$ and $u_{i}^{*}$ ), which depends on the second moments of the error terms $u_{1}, u_{0}$ and $u$, as discussed in detail in Lee (1978). For this reason, in the analysis below we will estimate both the Lee (1978) model, and a standard switching model (as in Equation 4). We compare the results from the two estimations to determine the sign of the selection coefficient.

Vector $X_{i}$ of Equations 2 and 3 contains the same firm variables considered in the previous multivariate analysis (profitability, size, leverage, industry, shares acquired, investment type, vintage, previous bank relationships, board seats). In addition to the variables that are in $X_{i}$, vector $Z_{i}$ also contains the following three instruments: stock market returns over the previous six months, defined as the returns on Italian equity market (S\&P Mib) over the six months preceding the investment start date; the average industry ROE, based on a two-digit SIC classification of Italian firms at the investment starting date; the average ratio of IPOs to newly created firms in Italy over the six months preceding the investment start date; average number of covenants employed in the deals that occurred in the previous six months. These variables represent potential instruments that may help with the identification of the model: they are exogenously given at the time of the investment; and by proxying for market and investment conditions they should correlate with the choice of covenants, thus satisfying the relevance condition.

We acknowledge that it is difficult to identify instruments that correlate with covenants but not with performance, and thus do not violate the exclusion condition. In particular, it may be that pre-deal market conditions affect IRR directly and not only via the choice of covenants. For example, consider the following mechanism suggested by Gompers and 
Lerner $(1999,2000)$ : as entry prices are influenced by market conditions, with prices being higher in heated markets than in low markets, IRR is a function of the share price at the time of contracting and at the time of exit. If this reasoning was correct, market conditions would not satisfy the exclusion condition when performance is measured with IRR. To avoid this problem, we employ other measures of performance (sales, ROA and ROE) alongside with IRR. These other measures appear less exposed to a violation of the exclusion condition because they do not depend on the entry price paid by the fund.

We construct a new dummy, covenant heavy, which takes value one if the covenant index is greater than its median value across the sample. The covenant heavy dummy and the three contracting styles identified above (incentives, default, protection) respectively represent the dependent variables in the criterion function of Equation (1).

\section{TABLE 7 ABOUT HERE}

We follow the estimation procedure sketched above. We start by estimating the reducedform model in Equation (5). We then obtain the inverse Mills ratios and use it to augment Equations (2) and (3), the estimates of which are reported in Table 7. The dependent variable changes across columns: it is IRR in columns 1a and 1b, change in sales in columns $2 \mathrm{a}$ and $2 \mathrm{~b}$, change in ROA in columns $3 \mathrm{a}$ and $3 \mathrm{~b}$, and change in ROE in Columns $4 \mathrm{a}$ and 4b. The coefficients in columns 1a, 2a, 3a and 4a are for Equation $(3)\left(I_{i}=0\right)$, while in columns $1 \mathrm{~b}, 2 \mathrm{~b}, 3 \mathrm{~b}$ and $4 \mathrm{~b}$ they are for Equation $(2)\left(I_{i}=1\right)$. The criterion functions $I_{i}$ refer to the inclusion/exclusion of different types of covenants in a deal: covenant heavy in Panel A, incentive covenants in Panel B, default covenants in Panel $\mathrm{C}$, and protection covenants in Panel D. In the table, we report the full set of regressions only for covenant heavy, while for the other three specifications of the criterion function (incentives, default, protection), we only report the coefficient of the inverse Mills ratio. 
The inverse Mills ratio is 1) always significant when covenant heavy is the selection variable, 2) generally significant for incentive and protection covenants (relatively more so for the latter), 3) almost always not significant for default covenants. These results suggest that there is a selection effect associated with the use of covenants, that the effect depends significantly on the covenants employed, and that the effect is stronger for protection and, albeit to a lesser extent, incentive covenants.

We next estimate the standard model outlined in Equation (4). In untabulated results we find that the coefficients of the inverse Mills ratios for the standard model are always positive and significant for covenant heavy deals and for incentive covenants; positive and significant for protection covenants, when the outcome is measured with IRR; generally, not significant for default covenants. ${ }^{12}$ Therefore, the standard switching model suggests that better firms are associated with having more covenants and with incentive and, albeit to a lesser extent, protection covenants. ${ }^{13}$

We also estimate counterfactuals by computing the predicted returns associated with the observations that carry covenants, using the estimated coefficients for the observations that do not carry covenants. ${ }^{14}$ Our estimations suggest that it is optimal for covenant laden firms, and for firms using incentive or protection covenants to make the choice of covenants that we observe in reality. For example, the estimated IRR for firms with

\footnotetext{
${ }^{12}$ We also construct three new dependent variables, given by the difference between IRR and, respectively, sales growth, ROA growth and ROE growth. We run the base selection model using these differences as dependent variables and covenant heavy as the selection variable. We observe a positive and significant coefficient for the inverse Mills ratio for the first two measures and insignificant for the third one. This result suggests that covenants are associated with more than proportionally higher returns for PE investors than for other types of investors.

${ }^{13}$ The results of the standard switching model can also be interepreted to indicate that one source of treatment effect is because the PE investor picks up a firm whose value is lower than it should be. However, this explanation is mainly suited to explain the effect that treatment has on IRR than on the other measures of performance (sales, ROA, ROE), that do not depend on entry and exit prices.

${ }^{14}$ Formally, the counterfactual for firms with covenants had they not used covenants is defined as $E\left(y_{1} \mid X, I=1, \beta_{0}\right)$, and the counterfactual for firms without covenants had they used covenants is $E\left(y_{0} \mid X, I=0, \beta_{1}\right)$. See Poon, Lee and Gup (2009) for comprehensive definitions of counterfactual measures in a switching model applied to solicited vs unsolicited bank ratings.
} 
incentive covenants $\left(I_{i}=1\right)$ is $20.5 \%$, while the counterfactual estimate for these firms is $11.1 \%$. For protection covenants, the corresponding figures are an estimated $10.8 \%$ vs. $4.8 \%$ had they not chosen the covenant. In contrast, firms that chose not to include protection or incentive covenants would have performed better had they chosen to include them.

Finally, we proceed to the last step of Lee's estimation procedure, and produce estimates of Equation (1) in which $y_{1 i}$ and $y_{0 i}$ are the values predicted by (2) and (3). Table 8 reports our estimation of $\gamma$, which is meant to capture how expected treatment effects influence the decision to include covenants. The table reports the coefficient of $\gamma$ obtained in all the possible combinations of selection variables (in columns) and outcome variables (in rows). The main finding of this estimation is that $\gamma$ is positive and significant for the covenant heavy dummy and for incentive covenants with respect to change in sales, ROA and ROE, while it is not significant for IRR. On the other hand, the coefficient is never significant for default and protection covenants.

\section{TABLE 8 ABOUT HERE}

\section{The Choice of Board Directors}

As shown by Barry et al. (1990), Lerner (1995) and Sahlman (1990), it is common practice in the U.S. for PE investors to elect one or more directors in the board of the firms in their portfolio. The role of these directors is to represent the interests of the PE fund by exerting direct oversight on the managers of the firm. In our sample deals we also find that the appointment of directors is a common phenomenon. Almost invariably PE funds appoint only one director, regardless of the percentage of shares acquired.

We classify appointed directors as outsiders and insiders, depending on whether 
the appointee is or has been an employee of the fund, or has strong ties with the fund. Our definition of insider is different from that employed by Lerner (1995), which classifies directors into outsiders and insiders with respect to their relationship with the firm, rather than with respect to the fund.

We want to investigate whether the appointment of a certain type of director is related to firm performance. We focus on the hypothesis suggested by Lerner (1995) that "if venture capitalists are intensive monitors of managers, their involvement as directors should be more intense when the need for oversight is greater." Therefore, we expect outsiders to be appointed in firms where less monitoring is required. These firms are likely to be the less risky and more profitable, which implies that we should observe a negative correlation between the appointment of insiders and returns. ${ }^{15}$

We provide four different measures of inside directors. Our first measure is based on the cumulative number of appointments held by any given director on behalf of the PE investor during the time of investment. A higher number means stronger ties with the fund. Our second measure is the cumulative number of appointments held by a director before the time of investment. This measure has the same meaning of the first one, but is backward looking. Third, we look at whether the director is or has been an employee of the fund. Fourth, we look at whether the appointment of the director has the same duration as the board of the target firm. A match of duration is typically observed when a director is an outsider. Table 5 provides summary statistics for each of these measures.

We now examine the relationship between the choice of directors and returns. We employ our four measures of inside directors. We first explore the univariate correlation between the choice of director and returns. In untabulated results, we find a negative

\footnotetext{
${ }^{15}$ An alternative hypothesis is that inside directors are busier and can exert less monitoring on the target firm, thus leading to poorer performance. This hypothesis is based on the idea of the inefficiency of busy directors originally developed by Fich and Shivdasani (2006). While this hypothesis appears well suited to large corporations, it does not fit well with the high-incentive enviroronment of PE partnerships
} 
relationship between the choice of an inside director and sales, ROA, and ROE, and a weak negative correlation between the choice of an inside director and an IPO. There is no significant unconditional correlation between IRR and the choice of an inside director.

We then analyze whether the relationship observed between returns and the presence of an inside director is robust in a multivariate setting. To examine the coefficients of the inside directors we look at the selectivity-bias adjusted regressions for all four measures of performance and all four measures of inside directors, thus obtaining sixteen coefficients for Equation (2) and sixteen coefficients for Equation (3). These coefficients are reported in the relevant row of Table 7 for the variable board seats during and in Table 9 for the other three measures of inside directors.

\section{TABle 9 ABOUt HeRE}

Our main finding from the two tables is that for all four measures of insider we observe a negative relationship with performance which is stronger for sales, ROA and ROE than for IRR. The explanation provided by Lerner (1995) that internal directors are appointed where there is a need for more intensive monitoring seems to be supported by the data for all four measures of board directors. It is also consistent with the weaker correlation between these measures and IRR. The interpretation of the latter result may be that even though insiders signal low firm prospects, the IRR of the investment is not affected as much as other measures of performance.

\section{Conclusions}

In this paper we examine the relationship between the returns of PE investments and contract characteristics. We identify covenants as the main object of analysis and find a 
strong positive relationship between the number of covenants included in a deal and deal returns. This relationship holds for different measures of returns (IRR, growth in sales, ROA and ROE). The relationship is robust after controlling for a number of firm, industry and investment characteristics.

We conjecture that the observed correlation between covenants and returns is caused by a self-selection process in which PE investors choose covenants based on their expectations of the target firm's future prospects. We use a three-stage methodology that allows us to (i) account for self-selection in the use of covenants, and (ii) for the possible treatment effects that covenants have performance. Our central finding is that self-selection plays a key role in the choice of covenants and more covenants are associated with better firm prospects. The choice of covenants reveals unobservable private information that is not otherwise observable by looking at public information, contained, for example, in accounting variables. We interpret this evidence to indicate that firms signal their better prospects to potential investors by accepting more covenants than average. We also show that covenants can carry treatment effects that likely operate by strengthening the incentives of managers towards profit maximization.

Finally, we examine the relationship between the appointment of board directors and returns. We find that internal directors are appointed in firms that are less profitable. We interpret this evidence as consistent with the hypothesis of Lerner (1995) that insiders are appointed when there is more need for close monitoring.

\section{Acknowledgments}

We thank MPS Venture SGR for kindly providing the data; Paul Gompers, Francesco Corielli, Douglas Cumming, John Doukas, Giuliano Iannotta, Josh Lerner, Marco Da Rin, Antoinette Schoar, Albrecht Glitz, two anonymous referees, and the editor Manju Puri for helpful comments. We also thank seminar participants at the Second Entrepreneurial 
Finance and Innovation Conference in Boston, EFA in Frankfurt, EFMA in Milan, EFMA Symposium on Private Equity in Montreal, and FMA in Reno. We acknowledge financial support from CAREFIN Centre for Applied Research in Finance. 
Aghion P., Bolton, P., Tirole, J., 2004. Exit Options in Corporate Finance: Liquidity versus Incentives. Rev. Finance 8, 327-353.

Aghion, P., Bolton, P., 1992. An Incomplete Contracts Approach to Financial Contracting. Rev. Econ. Stud. 77, 338-101.

Axelson, U., Jenkinson, T., Strömberg, P., Weisbach, M.S., 2012. Borrow Cheap, Buy High? Determinants of Leverage and Pricing in Buyouts. J. of Finance, Forthcoming.

Barry, C.B., Muscarella, C.J., Peavy, J.W., Vetsuypens, M.R., 1990. The Role of Venture Capital in the Creation of Public Companies: Evidence from the Going-Public Process. J. Finan. Econ. 27, 447-471.

Bascha, A., Walz, U., 2001. Convertible Securities and Optimal Exit Decisions in Venture Capital Finance. J. Corp. Fin. 7, 285-306.

Bengtsson, O., 2011, Covenants in Venture Capital Contracts, Manag. Science 57 (11), 1926-1943

Brav, A., Gompers, P.A., 2003. The Role of Lockups in Initial Public Offerings. Rev. Finan. Stud. $16(1), 1-29$.

Bygrave, W., Timmons, J., 1992. Venture Capital at the Crossroads. Harvard Business School Press, Boston.

Casamatta, C. , 2003. Financing and Advising: Optimal Financial Contracts with Venture Capitalists. J. of Finance 58(5), 2059-2085.

Casares-Field L., Hanka, G., 2001. The Expiration of IPO Share Lockups. J. of Finance 56(2), $471-500$.

Cochrane, J. H. , 2005. The Risk and Return of Venture Capital. J. Finan. Econ. 75(1), 3-52.

Cornelli, F., Yosha, O., 2003. Stage Financing and the Role of Convertible Securities. Rev. Econ. Stud. 70(1), $1-32$.

Cumming, D., 2008. Contracts and Exits in Venture Capital Finance. Rev. Finan. Stud. 21(5), 1947-1982.

Dessi, R., 2005. Start-up Finance, Monitoring and Collusion. RAND J. Econ. 36 (2), 255-274.

Drucker, S., Puri, M., 2009. On Loan Sales, Loan Contracting, and Lending Relationships. Rev. Finan. Stud. 22 (7), 2835-2872.

Dunbar, C.G., 1995. The Use of Warrants as Underwriter Compensation in Initial Public Offerings. J. Finan. Econ. 38, 59-78.

Fang, L.H., 2005. Investment Bank Reputation and the Price and Quality of Underwriting Services. J. of Finance 60 (6), 2729-2761.

Fich, E.M., Shivdasani, A. , 2006. Are Busy Boards Effective Monitors?. J. of Finance 61 (2), 689-724.

Gompers, P., Lerner J., 1997. Risk and Reward in Private Equity Investments: the Challenge of Performance Assessment. J. Priv. Equity 1, 5-12.

Gompers, P., Lerner, J. , 1999. An Analysis of Compensation in the U.S. Venture Capital Partnership. J. Finan. Econ. 51(1), 3-44.

Gompers, P., Lerner, J. , 2000. Money Chasing Deals? The Impact of Fund Inflows in Private Equity Valuations. J. Finan. Econ. 55, 281-325. 
Gompers, P.A., 1999. Ownership and Control in Entrepreneurial Firms: An Examination of Convertible Securities in Venture Capital Investments. Unpublished results.

Goyal, V.K., 2005. Market Discipline of Bank Risk: Evidence from Subordinated Debt Contracts. J. Fin. Inter. 14, 318-350.

Groh, A., Gottschalg, O., 2006. The Risk-Adjusted Returns of U.S. Buyouts. Unpublished results.

Heckman, J.J., 1979. Sample Selection as a Specification Error. Econometrica 47, 153-161.

Hellmann, T., 1998. The Allocation of Control Rights in Venture Capital Contracts. RAND J. Econ. $29(1), 57-76$.

Hellmann, T., 2006. IPOs, Acquisitions, and the Use of Convertible Securities in Venture Capital. J. Finan. Econ. 81, 649-79.

Holmström, B., 1979. Moral Hazard and Observability. Bell J. Econ. 10, 74-91.

Inderst, R., Mueller, H., 2004. The Effect of Capital Market Characteristics in the Value of Start-Up Firms. J. Finan. Econ. 72, 319-356.

Johnson, R. A., Wichern, D.A., 2007, Applied Multivariate Statistical Analysis, sixth ed., Pearson Prentice Hall, NJ.

Kaplan, S., Schoar, A., 2005. Private Equity Performance: Returns, Persistence and Capital Flows. J. of Finance 60 (4), 1791-1823.

Kaplan, S. N., Strömberg, P., 2003. Financial Contracting Theory Meets the Real World: An Empirical Analysis of Venture Capital Contracts. Rev. Econ. Stud., 70(2), 281-315.

Kaplan, S. N., Strömberg, P., 2004. Characteristics, Contracts, and Actions: Evidence from Venture Capitalist Analyses. J. of Finance 59(5), 2173-2206.

Lee, L.F., 1978. Unionism and Wage Rates: a Simultaneous Equations Model with Quantitative and Limited Dependent Variables. Intern. Econ. Rev. 19, 415-433.

Lerner, J., 1995. Venture Capitalists and the Oversight of Private Firms. J. of Finance 50, 301-318.

Lerner, J., Merges, R.P., 1998. The Control of Technology Alliances: An Empirical Analysis of the Biotechnology Industry. J. Indus. Econ. 46(2), 125-56.

Lerner, J., Schoar, A., Wong, W., 2007. Smart Institutions, Foolish Choices?: The Limited Partner returns Puzzle. J. of Finance 62, 731-64.

Li, K., Prabhala, N.R., 2007. Self-Selection Models in Corporate Finance, in: Eckbo, B.E., (Eds.), Handbook of Corporate Finance, Volume I, North Holland, pp. 37-83.

Ljungqvist, A., Richardson, M., 2003. The Cash-Flow, Return and Risk Characteristics of Private Equity. Unpublished results.

Metrick, A., Yasuda, A., 2010. The Economics of Private Equity Funds. Rev. Finan. Stud. 23, 2303-2341.

Phalippou, L., Gottschalg, O., 2009. The returns of Private Equity Funds. Rev. Finan. Stud. 22(4), 1747-1776.

Poon, W.P.H., Lee, J. and Gup, B.E., 2009, Do Solicitations Matter in Bank Credit Ratings? Results from a Study of 72 Countries. J. Money, Cred. Bank. 41: 285-314.

Puri, M., 1996. Commercial Banks in Investment Banking: Conflict of Interest or Certification Role?. J. Finan. Econ. 40, 373-401. 
Renucci, A., 2000. Optimal Contracts between Entrepreneurs and Value-enhancing Financiers. Unpublished results.

Repullo, R., Suarez, J., 2004. Venture Capital Finance: A Security Design Approach. Rev. Finance 8(1), 75-108.

Sahlman, W. A., 1990. The Structure and Governance of Venture Capital Organizations. J. Finan. Econ. 27, 473-521.

Schmidt, K.M., 2003. Convertible Securities and Venture Capital Finance.J. of Finance 58 (5), 2059-86.

Song, W., 2004. Competition and Coalition among Underwriters: The Decision to Join a Syndicate. J. of Finance 59, 2421-2444.

Sufi, Amir. (2009). Bank Lines of Credit in Corporate Finance: An Empirical Analysis. Rev. Finan. Stud., 22(3), 1057-1088

Yates, G., Hinchliffe, M., 2010. A Practical Guide to Private Equity Transactions. Cambridge University Press, Cambridge. 
Table 1

Investment Returns

\begin{tabular}{|c|c|c|c|c|c|c|c|c|c|c|}
\hline & & \multirow[b]{2}{*}{$\begin{array}{l}\text { All } \\
(\%)\end{array}$} & \multicolumn{4}{|c|}{ Type } & \multicolumn{4}{|c|}{ Exit } \\
\hline & & & $\begin{array}{c}\text { Early } \\
(\%)\end{array}$ & $\begin{array}{c}\text { Exp. } \\
(\%)\end{array}$ & $\begin{array}{c}\text { Buy. } \\
(\%)\end{array}$ & $\begin{array}{c}\text { Turn. } \\
(\%)\end{array}$ & $\begin{array}{c}\text { Trade } \\
(\%)\end{array}$ & $\begin{array}{l}\text { IPO } \\
(\%)\end{array}$ & $\begin{array}{c}\text { W-Off } \\
(\%)\end{array}$ & $\begin{array}{c}\text { Unexit. } \\
(\%)\end{array}$ \\
\hline \multirow[t]{2}{*}{ IRR } & Mean & 9.40 & 1.64 & 11.23 & 11.99 & 3.33 & 13.33 & 32.19 & -57.87 & -2.60 \\
\hline & Med. & 10.61 & 8.32 & 10.71 & 12.03 & 12.80 & 10.86 & 28.44 & -54.07 & -4.32 \\
\hline \multirow[t]{2}{*}{$\Delta$ Sales } & Mean & 6.68 & 3.82 & 6.83 & 7.98 & 7.67 & 7.11 & 13.47 & -2.88 & -0.01 \\
\hline & Med. & 3.92 & 2.46 & 3.92 & 4.97 & 4.23 & 4.14 & 9.99 & -0.06 & -3.63 \\
\hline \multirow[t]{2}{*}{$\triangle \mathrm{ROA}$} & Mean & 6.01 & 3.05 & 6.21 & 7.27 & 6.90 & 6.34 & 11.90 & -2.59 & 0.05 \\
\hline & Med. & 3.19 & 1.95 & 3.15 & 4.18 & 3.85 & 3.35 & 8.36 & -0.32 & 0.39 \\
\hline \multirow[t]{2}{*}{$\triangle \mathrm{ROE}$} & Mean & 17.59 & 7.23 & 18.21 & 22.20 & 20.88 & 19.24 & 27.48 & -8.09 & -1.18 \\
\hline & Med. & 7.23 & 5.20 & 7.73 & 8.82 & 8.24 & 7.98 & 18.27 & -0.51 & 0.01 \\
\hline
\end{tabular}

This table provides descriptive statistics for investment performance across different investment types and exits. The sample size consists of 834 deals. All values are reported as percentages. For unexited deals, IRR is estimated on the basis of the change in net asset value from investment date do the date of data collection (May 2011).

Table 2

Definitions of Covenants and Directors

\begin{tabular}{|c|c|}
\hline Lockup & $\begin{array}{l}\text { A provision in the underwriting agreement between some or all existing shareholders that } \\
\text { prohibits the sale of shares before a predetermined date. }\end{array}$ \\
\hline Permitted Transfer & $\begin{array}{l}\text { The permission to a } \mathrm{VC} \text { to make transfers of shares without pre-emption in favor of the remaining } \\
\text { shareholders. The types of permitted transfers may vary according to the class of shares. There } \\
\text { will usually be a permitted transfer provision allowing transfers between two or more separate } \\
\text { funds managed by the same VC. }\end{array}$ \\
\hline Redemption right & $\begin{array}{l}\text { Rights to force the company to purchase shares (a "put"). A redemption right allows one } \\
\text { shareholder to liquidate an investment in the event an IPO or a public merger becomes unlikely. } \\
\text { One may also negotiate a redemption provision to become effective when the company defaults } \\
\text { or fails to make payments upon a key employee's death, etc. }\end{array}$ \\
\hline Tag-along Rights & $\begin{array}{l}\text { A minority shareholder protection affording the right to include their shares in any sale of control } \\
\text { and at the offered price ("right of co-sale") }\end{array}$ \\
\hline Drag-along Rights & $\begin{array}{l}\text { A majority shareholders right, obligating minority shareholders whose shares are bound into the } \\
\text { agreement, to sell their shares into an offer the majority wishes to execute. }\end{array}$ \\
\hline Right of First Refusal & $\begin{array}{l}\text { A negotiated obligation of the company or existing investors to offer shares to the company or } \\
\text { other existing investors at fair market value or a previously negotiated price, prior to selling } \\
\text { shares to new investors ("pre-emption right"). }\end{array}$ \\
\hline Exit Ratchet & $\begin{array}{l}\text { An exit ratchet is used to adjust the respective shareholdings of the VCs and insiders depending } \\
\text { on either the level of returns or on an exit. This clause is principally used to provide additional } \\
\text { incentives/rewards to the managers for delivering high returns to investors. }\end{array}$ \\
\hline
\end{tabular}


Table 3

Covenants

\begin{tabular}{|c|c|c|c|c|c|c|c|c|c|c|}
\hline & & \multirow[b]{2}{*}{$\begin{array}{l}\text { All } \\
(\%)\end{array}$} & \multicolumn{4}{|c|}{ Type } & \multicolumn{4}{|c|}{ Exit } \\
\hline & & & $\begin{array}{c}\text { Early } \\
(\%)\end{array}$ & $\begin{array}{l}\text { Exp. } \\
(\%)\end{array}$ & $\begin{array}{c}\text { Buy. } \\
(\%)\end{array}$ & $\begin{array}{c}\text { Turn. } \\
(\%)\end{array}$ & $\begin{array}{c}\text { Trade } \\
(\%)\end{array}$ & $\begin{array}{l}\text { IPO } \\
(\%)\end{array}$ & $\begin{array}{c}\text { W-Off } \\
(\%)\end{array}$ & $\begin{array}{c}\text { Unexit. } \\
(\%)\end{array}$ \\
\hline Lockup & 55 & 6.59 & 11.43 & 5.20 & 6.64 & 4.44 & 2.48 & 79.07 & 1.82 & 18.18 \\
\hline Permitted transfer & 157 & 18.82 & 13.57 & 19.62 & 20.80 & 17.78 & 15.17 & 76.74 & 20.00 & 27.27 \\
\hline Redemption right & 156 & 18.71 & 14.29 & 17.02 & 24.78 & 17.78 & 15.03 & 72.09 & 18.18 & 54.55 \\
\hline Tag-along right & 725 & 86.93 & 85.00 & 87.94 & 85.40 & 91.11 & 86.76 & 95.35 & 85.45 & 72.73 \\
\hline Drag-along right & 172 & 20.62 & 20.00 & 21.04 & 20.35 & 20.00 & 20.55 & 16.28 & 18.18 & 54.55 \\
\hline First refusal & 73 & 8.75 & 9.29 & 7.57 & 11.95 & 2.22 & 5.24 & 65.12 & 5.45 & 36.36 \\
\hline Exit ratchet & 65 & 7.79 & 3.57 & 7.33 & 11.06 & 8.89 & 6.62 & 25.58 & 9.09 & 9.09 \\
\hline Incentive Cov. & 151 & 18.57 & 16.08 & 22.57 & 13.33 & 18.57 & 13.38 & 95.35 & 14.55 & 45.45 \\
\hline Protection Cov. & 262 & 26.43 & 30.26 & 36.73 & 31.11 & 26.43 & 27.45 & 93.02 & 29.09 & 63.64 \\
\hline Default Cov. & 751 & 89.29 & 89.60 & 90.27 & 95.56 & 89.29 & 89.93 & 95.35 & 89.09 & 81.82 \\
\hline
\end{tabular}

This table provides descriptive statistics for covenants across different investment types and exits. The sample size consists of 834 deals. The first column reports the number of investments carrying a specific covenant, while in the other columns we report percentages. Incentive Covenants include lockup, right of first refusal, and exit ratchets. Protection Covenants include redemption rights and permitted transfers. Default Covenants include tag and drag-along rights. 
Table 4

Univariate Differences in Performance Accounting for the Use of Covenants

Panel A - IRR

\begin{tabular}{|c|c|c|c|c|c|c|}
\hline $\mathrm{X}$ & $\begin{array}{c}\text { IRR if } X=0 \\
(\%)\end{array}$ & $\begin{array}{c}\text { IRR if } X=1 \\
(\%)\end{array}$ & t-test & p-value & Wilcoxon z & p-value \\
\hline Lockup & 8.45 & 22.87 & -5.171 & 0.000 & -4.345 & 0.000 \\
\hline Permitted transfer & 8.87 & 11.69 & -1.237 & 0.217 & -1.615 & 0.053 \\
\hline Redemption right & 8.98 & 11.24 & -1.109 & 0.269 & -0.502 & 0.308 \\
\hline Tag-along right & 4.97 & 10.07 & -1.732 & 0.086 & -2.507 & 0.006 \\
\hline Drag-along right & 9.54 & 8.87 & 0.350 & 0.726 & 2.270 & 0.012 \\
\hline First refusal & 8.93 & 14.31 & -1.790 & 0.077 & -1.122 & 0.131 \\
\hline Exit ratchet & 7.63 & 30.44 & -5.378 & 0.000 & -7.054 & 0.000 \\
\hline Incentive Covenants & 7.03 & 20.16 & -5.668 & 0.000 & -5.282 & 0.000 \\
\hline Protection Covenants & 8.82 & 10.69 & -1.057 & 0.291 & -0.686 & 0.246 \\
\hline Default Covenants & 6.99 & 9.67 & -0.824 & 0.412 & -0.659 & 0.255 \\
\hline \multicolumn{7}{|l|}{ Panel B $-\Delta$ Sales } \\
\hline $\mathrm{X}$ & $\begin{array}{l}\Delta \text { Sales if } \\
X=0(\%)\end{array}$ & $\begin{array}{l}\Delta \text { Sales if } \\
X=1(\%)\end{array}$ & t-test & p-value & Wilcoxon $\mathrm{z}$ & p-value \\
\hline Lockup & 6.26 & 12.71 & -3.789 & 0.000 & -5.296 & 0.000 \\
\hline Permitted transfer & 6.53 & 7.35 & -0.785 & 0.433 & -0.713 & 0.238 \\
\hline Redemption right & 6.86 & 5.91 & 1.053 & 0.293 & 0.550 & 0.291 \\
\hline Tag-along right & 6.50 & 6.71 & -0.180 & 0.857 & 0.128 & 0.449 \\
\hline Drag-along right & 6.95 & 5.68 & 1.337 & 0.182 & 1.859 & 0.031 \\
\hline First refusal & 6.60 & 7.56 & -0.643 & 0.522 & -1.671 & 0.047 \\
\hline Exit ratchet & 5.43 & 21.48 & -5.610 & 0.000 & -6.636 & 0.000 \\
\hline Incentive Covenants & 5.18 & 13.50 & -5.600 & 0.000 & -6.496 & 0.000 \\
\hline Protection Covenants & 6.82 & 6.40 & 0.526 & 0.599 & 0.578 & 0.282 \\
\hline Default Covenants & 6.92 & 6.66 & 0.203 & 0.839 & 0.924 & 0.178 \\
\hline
\end{tabular}

This table shows the difference in performance between investments respectively with and without a specific covenant. To test for differences we employ a t- and a Wilcoxon test. 
Table 5

Summary Statistics of Main Variables

\begin{tabular}{|c|c|c|c|c|c|}
\hline \multirow{2}{*}{ 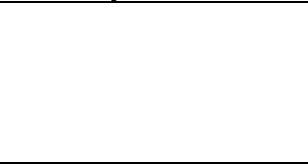 } & \multirow{2}{*}{ Variable Definition } & \multirow[b]{2}{*}{$\begin{array}{c}\text { Mean } \\
{[\text { Median }]}\end{array}$} & \multicolumn{3}{|c|}{ Correlations (p-values) with: } \\
\hline & & & $\begin{array}{l}\text { Covenant } \\
\text { Index }\end{array}$ & IRR & $\Delta$ Sales \\
\hline Profitability & EBIDTA/Assets & $\begin{array}{c}0.169 \\
{[0.114]}\end{array}$ & $\begin{array}{c}0.141 \\
(0.000)\end{array}$ & $\begin{array}{l}-0.068 \\
(0.046)\end{array}$ & $\begin{array}{l}-0.079 \\
(0.022)\end{array}$ \\
\hline Size & Log of Assets & $\begin{array}{c}4.212 \\
{[4.205]}\end{array}$ & $\begin{array}{l}-0.023 \\
(0.503)\end{array}$ & $\begin{array}{c}0.198 \\
(0.000)\end{array}$ & $\begin{array}{c}0.184 \\
(0.000)\end{array}$ \\
\hline Leverage & Book Value of Debt/Assets & $\begin{array}{c}0.791 \\
{[0.799]}\end{array}$ & $\begin{array}{l}-0.081 \\
(0.018)\end{array}$ & $\begin{array}{l}-0.012 \\
(0.730)\end{array}$ & $\begin{array}{l}-0.021 \\
(0.539)\end{array}$ \\
\hline$\%$ shares & Percentage of shares acquired by the fund & $\begin{array}{c}0.227 \\
{[0.250]}\end{array}$ & $\begin{array}{l}-0.064 \\
(0.063)\end{array}$ & $\begin{array}{l}-0.020 \\
(0.553)\end{array}$ & $\begin{array}{l}-0.053 \\
(0.123)\end{array}$ \\
\hline $\begin{array}{l}\text { Board Seats During } \\
\text { the Investment }\end{array}$ & $\begin{array}{l}\text { Number of other board seats held during the } \\
\text { investment on behalf of the fund }\end{array}$ & $\begin{array}{c}6.718 \\
{[7.000]}\end{array}$ & $\begin{array}{l}-0.007 \\
(0.843)\end{array}$ & $\begin{array}{c}0.047 \\
(0.173)\end{array}$ & $\begin{array}{l}-0.012 \\
(0.738)\end{array}$ \\
\hline $\begin{array}{l}\text { Board Seats Before } \\
\text { the Investment }\end{array}$ & $\begin{array}{l}\text { Number of board seats held before the } \\
\text { investment on behalf of the fund }\end{array}$ & $\begin{array}{c}6.597 \\
{[7.000]}\end{array}$ & $\begin{array}{l}-0.053 \\
(0.119)\end{array}$ & $\begin{array}{c}0.025 \\
(0.459)\end{array}$ & $\begin{array}{l}-0.038 \\
(0.272)\end{array}$ \\
\hline Employee & Dummy $=1$ if board director is an employee & $\begin{array}{c}0.456 \\
{[0.000]}\end{array}$ & $\begin{array}{c}0.006 \\
(0.865)\end{array}$ & $\begin{array}{c}0.026 \\
(0.455)\end{array}$ & $\begin{array}{c}0.123 \\
(0.000)\end{array}$ \\
\hline $\begin{array}{l}\text { No Match of } \\
\text { Duration }\end{array}$ & $\begin{array}{l}\text { Dummy }=1 \text { if mandate of director and } \\
\text { board do not match }\end{array}$ & $\begin{array}{c}0.366 \\
{[0.000]}\end{array}$ & $\begin{array}{c}0.010 \\
(0.773)\end{array}$ & $\begin{array}{c}0.051 \\
(0.133)\end{array}$ & $\begin{array}{c}0.080 \\
(0.020)\end{array}$ \\
\hline Bank Ownership & Dummy $=1$ if the fund is owned by a bank & $\begin{array}{c}0.607 \\
{[1.000]}\end{array}$ & $\begin{array}{l}-0.021 \\
(0.546)\end{array}$ & $\begin{array}{l}-0.034 \\
(0.325)\end{array}$ & $\begin{array}{l}-0.069 \\
(0.042)\end{array}$ \\
\hline Bank Relationships & $\begin{array}{l}\text { Dummy }=1 \text { if the fund is owned by a bank } \\
\text { that provides credit to the firm }\end{array}$ & $\begin{array}{c}0.488 \\
{[0.000]}\end{array}$ & $\begin{array}{c}0.001 \\
(0.982)\end{array}$ & $\begin{array}{l}-0.033 \\
(0.342)\end{array}$ & $\begin{array}{l}-0.096 \\
(0.005)\end{array}$ \\
\hline Market Returns $6 \mathrm{~m}$ & $\begin{array}{l}\text { Returns on S\&P MIB over previous } 6 \\
\text { months }\end{array}$ & $\begin{array}{c}0.165 \\
{[0.153]}\end{array}$ & $\begin{array}{c}0.160 \\
(0.000)\end{array}$ & $\begin{array}{c}0.114 \\
(0.001)\end{array}$ & $\begin{array}{c}0.089 \\
(0.009)\end{array}$ \\
\hline Industry ROE & Average industry ROE at time of investment & $\begin{array}{c}8.071 \\
{[7.805]}\end{array}$ & $\begin{array}{c}0.092 \\
(0.007)\end{array}$ & $\begin{array}{l}-0.055 \\
(0.107)\end{array}$ & $\begin{array}{l}-0.043 \\
(0.212)\end{array}$ \\
\hline IPO/New & $\begin{array}{l}\text { Ratio of IPOs to newly created firms created } \\
\text { over previous } 6 \text { months }\end{array}$ & $\begin{array}{c}0.156 \\
{[0.119]}\end{array}$ & $\begin{array}{c}0.010 \\
(0.773)\end{array}$ & $\begin{array}{l}-0.100 \\
(0.003)\end{array}$ & $\begin{array}{l}-0.170 \\
(0.000)\end{array}$ \\
\hline $\begin{array}{l}\text { Average Number of } \\
\text { Covenants } 6 \mathrm{~m}\end{array}$ & $\begin{array}{l}\text { Average number of covenants per deal in the } \\
\text { previous } 6 \text { months }\end{array}$ & $\begin{array}{c}1.710 \\
{[1.693]}\end{array}$ & $\begin{array}{c}0.189 \\
(0.000)\end{array}$ & $\begin{array}{r}-0.0122 \\
(0.721)\end{array}$ & $\begin{array}{l}-0.092 \\
(0.007)\end{array}$ \\
\hline
\end{tabular}

This table provides definitions and summary statistics for the key variables employed in the analysis, as well as their pairwise correlation with IRR and growth in sales. 
Table 6

Regressions of Performance on Covenants

Panel A - Performance and Covenant Index

\begin{tabular}{|c|c|c|c|c|c|c|}
\hline & $\begin{array}{c}(1) \\
\text { OLS } \\
\text { IRR }\end{array}$ & $\begin{array}{c}(2) \\
\text { OLS } \\
\Delta \text { Sales } \\
\end{array}$ & $\begin{array}{c}(3) \\
\text { OLS } \\
\Delta \text { ROA }\end{array}$ & $\begin{array}{c}(4) \\
\text { OLS } \\
\Delta \mathrm{ROE} \\
\end{array}$ & $\begin{array}{c}(5) \\
\text { Probit } \\
\text { IPO } \\
\end{array}$ & $\begin{array}{c}(6) \\
\text { Probit } \\
\text { Write-off }\end{array}$ \\
\hline Covenant Index & $\begin{array}{c}0.046^{* * *} \\
(0.007)\end{array}$ & $\begin{array}{c}0.018 * * * \\
(0.004)\end{array}$ & $\begin{array}{c}0.014 * * * \\
(0.003)\end{array}$ & $\begin{array}{c}0.035 * * * \\
(0.011)\end{array}$ & $\begin{array}{c}1.933 * * * \\
(0.227)\end{array}$ & $\begin{array}{l}-0.066 \\
(0.063)\end{array}$ \\
\hline Profitability & $\begin{array}{l}-0.029 \\
(0.054)\end{array}$ & $\begin{array}{l}-0.036 \\
(0.031)\end{array}$ & $\begin{array}{l}-0.031 \\
(0.028)\end{array}$ & $\begin{array}{c}-0.200 * * \\
(0.089)\end{array}$ & $\begin{array}{c}0.605 \\
(0.652)\end{array}$ & $\begin{array}{c}0.087 \\
(0.322)\end{array}$ \\
\hline Size & $\begin{array}{c}0.050 * * \\
(0.024)\end{array}$ & $\begin{array}{c}0.014 * \\
(0.009)\end{array}$ & $\begin{array}{l}0.014 * \\
(0.008)\end{array}$ & $\begin{array}{c}0.030 \\
(0.026)\end{array}$ & $\begin{array}{l}-0.225 \\
(0.435)\end{array}$ & $\begin{array}{l}-0.201 \\
(0.156)\end{array}$ \\
\hline Leverage & $\begin{array}{l}-0.454 * \\
(0.240)\end{array}$ & $\begin{array}{l}-0.172 \\
(0.143)\end{array}$ & $\begin{array}{l}-0.116 \\
(0.110)\end{array}$ & $\begin{array}{l}-0.250 \\
(0.353)\end{array}$ & $\begin{array}{c}-10.948 * * \\
(5.043)\end{array}$ & $\begin{array}{l}3.795^{*} \\
(2.164)\end{array}$ \\
\hline Bank Relationship & $\begin{array}{l}-0.015 \\
(0.019)\end{array}$ & $\begin{array}{l}-0.021 \\
(0.013)\end{array}$ & $\begin{array}{l}-0.018 \\
(0.013)\end{array}$ & $\begin{array}{l}-0.072 \\
(0.044)\end{array}$ & $\begin{array}{c}0.263 \\
(0.263)\end{array}$ & $\begin{array}{l}-0.083 \\
(0.126)\end{array}$ \\
\hline$\%$ Shares & $\begin{array}{c}0.182 \\
(0.176)\end{array}$ & $\begin{array}{c}0.056 \\
(0.067)\end{array}$ & $\begin{array}{c}0.023 \\
(0.065)\end{array}$ & $\begin{array}{l}-0.005 \\
(0.227)\end{array}$ & $\begin{array}{l}7.197 * * \\
(3.484)\end{array}$ & $\begin{array}{l}-0.817 \\
(1.215)\end{array}$ \\
\hline Board Seats & $\begin{array}{l}-0.001 \\
(0.003)\end{array}$ & $\begin{array}{l}-0.001 \\
(0.001)\end{array}$ & $\begin{array}{c}-0.004 * * * \\
(0.001)\end{array}$ & $\begin{array}{c}-0.014 * * \\
(0.006)\end{array}$ & $\begin{array}{c}-0.127 * * \\
(0.056)\end{array}$ & $\begin{array}{c}0.009 \\
(0.022)\end{array}$ \\
\hline Constant & $\begin{array}{c}0.109 \\
(0.179)\end{array}$ & $\begin{array}{c}0.072 \\
(0.126)\end{array}$ & $\begin{array}{c}0.091 \\
(0.092)\end{array}$ & $\begin{array}{c}0.349 \\
(0.299)\end{array}$ & $\begin{array}{c}0.921 \\
(2.547)\end{array}$ & $\begin{array}{c}-5.100 * * * \\
(1.871)\end{array}$ \\
\hline Observations & 834 & 834 & 834 & 834 & 789 & 823 \\
\hline Adj (Pse) $R^{2}$ & 0.104 & 0.130 & 0.115 & 0.067 & 0.771 & 0.0948 \\
\hline Industry FE & YES & YES & YES & YES & YES & YES \\
\hline Investment FE & YES & YES & YES & YES & YES & YES \\
\hline Year FE & YES & YES & YES & YES & YES & YES \\
\hline Investm. Duration & NO & $\mathrm{NO}$ & $\mathrm{NO}$ & $\mathrm{NO}$ & YES & YES \\
\hline
\end{tabular}


Panel B - Performance and Single Covenants

\begin{tabular}{|c|c|c|c|c|c|c|}
\hline Covenants & $\begin{array}{c}(1) \\
\text { OLS } \\
\Delta \text { Sales }\end{array}$ & $\begin{array}{c}(2) \\
\text { OLS } \\
\text { IRR }\end{array}$ & $\begin{array}{c}(3) \\
\text { OLS } \\
\Delta \mathrm{ROA}\end{array}$ & $\begin{array}{c}(4) \\
\mathrm{OLS} \\
\Delta \mathrm{ROE}\end{array}$ & $\begin{array}{c}(5) \\
\text { Probit } \\
\text { IPO }\end{array}$ & $\begin{array}{c}\text { (6) } \\
\text { Probit } \\
\text { Write-off }\end{array}$ \\
\hline Lockup & $\begin{array}{c}0.182 * * * \\
(0.027)\end{array}$ & $\begin{array}{c}0.073 * * * \\
(0.022)\end{array}$ & $\begin{array}{c}0.052 * * * \\
(0.014)\end{array}$ & $\begin{array}{c}0.093 * * \\
(0.039)\end{array}$ & $\begin{array}{c}3.786 * * * \\
(0.539)\end{array}$ & $\begin{array}{l}-0.673 * \\
(0.381)\end{array}$ \\
\hline Perm.Trans & $\begin{array}{c}0.045 * * \\
(0.017)\end{array}$ & $\begin{array}{c}0.018 * * \\
(0.007)\end{array}$ & $\begin{array}{l}0.013 * \\
(0.007)\end{array}$ & $\begin{array}{c}0.008 \\
(0.030)\end{array}$ & $\begin{array}{c}1.630 * * * \\
(0.202)\end{array}$ & $\begin{array}{c}0.009 \\
(0.160)\end{array}$ \\
\hline Redemption & $\begin{array}{c}0.039 * * \\
(0.018)\end{array}$ & $\begin{array}{c}0.001 \\
(0.007)\end{array}$ & $\begin{array}{l}-0.000 \\
(0.006)\end{array}$ & $\begin{array}{l}-0.022 \\
(0.024)\end{array}$ & $\begin{array}{c}1.711 * * * \\
(0.205)\end{array}$ & $\begin{array}{c}0.001 \\
(0.185)\end{array}$ \\
\hline Tag-along & $\begin{array}{c}0.034 \\
(0.029)\end{array}$ & $\begin{array}{c}0.003 \\
(0.009)\end{array}$ & $\begin{array}{l}-0.001 \\
(0.010)\end{array}$ & $\begin{array}{l}-0.032 \\
(0.054)\end{array}$ & $\begin{array}{c}0.980 * * * \\
(0.366)\end{array}$ & $\begin{array}{l}-0.123 \\
(0.260)\end{array}$ \\
\hline Drag-along & $\begin{array}{c}0.018 \\
(0.016)\end{array}$ & $\begin{array}{c}0.002 \\
(0.008)\end{array}$ & $\begin{array}{c}0.001 \\
(0.007)\end{array}$ & $\begin{array}{c}-0.007 \\
(0.033)\end{array}$ & $\begin{array}{l}-0.044 \\
(0.204)\end{array}$ & $\begin{array}{l}-0.096 \\
(0.217)\end{array}$ \\
\hline First Refus. & $\begin{array}{c}0.095 * * * \\
(0.026)\end{array}$ & $\begin{array}{c}0.022 \\
(0.015)\end{array}$ & $\begin{array}{c}0.012 \\
(0.013)\end{array}$ & $\begin{array}{l}-0.007 \\
(0.042)\end{array}$ & $\begin{array}{c}2.294 * * * \\
(0.197)\end{array}$ & $\begin{array}{l}-0.247 \\
(0.304)\end{array}$ \\
\hline Exit Ratchet & $\begin{array}{c}0.212 * * * \\
(0.046)\end{array}$ & $\begin{array}{c}0.155^{* * *} \\
(0.035)\end{array}$ & $\begin{array}{c}0.141 * * * \\
(0.036)\end{array}$ & $\begin{array}{c}0.561 * * * \\
(0.171)\end{array}$ & $\begin{array}{c}0.976 * * * \\
(0.224)\end{array}$ & $\begin{array}{l}-0.016 \\
(0.293)\end{array}$ \\
\hline Incentive Cov. & $\begin{array}{c}0.156 * * * \\
(0.023)\end{array}$ & $\begin{array}{c}0.092 * * * \\
(0.019)\end{array}$ & $\begin{array}{c}0.081 * * * \\
(0.018)\end{array}$ & $\begin{array}{c}0.289 * * * \\
(0.087)\end{array}$ & $\begin{array}{c}2.996 * * * \\
(0.317)\end{array}$ & $\begin{array}{l}-0.146 \\
(0.193)\end{array}$ \\
\hline Protection Cov. & $\begin{array}{c}0.038 * * \\
(0.017)\end{array}$ & $\begin{array}{c}0.006 \\
(0.006)\end{array}$ & $\begin{array}{c}0.005 \\
(0.006)\end{array}$ & $\begin{array}{l}-0.008 \\
(0.024)\end{array}$ & $\begin{array}{c}1.973 * * * \\
(0.230)\end{array}$ & $\begin{array}{l}-0.069 \\
(0.155)\end{array}$ \\
\hline Default Cov. & $\begin{array}{c}0.022 \\
(0.034)\end{array}$ & $\begin{array}{c}0.002 \\
(0.012)\end{array}$ & $\begin{array}{c}0.000 \\
(0.013)\end{array}$ & $\begin{array}{l}-0.020 \\
(0.058)\end{array}$ & $\begin{array}{c}0.729 * * \\
(0.334)\end{array}$ & $\begin{array}{l}-0.146 \\
(0.292)\end{array}$ \\
\hline
\end{tabular}

This table examines the relationship between covenants and performance in a multivariate setting. In Panel A we regress each measure of performance on the covenant index, also controlling for firm characteristics, investment type, year, and industry fixed effects. In Panel B each performance measure is regressed on each covenant individually, as well as on the three subsets incentive, protection, default, again controlling for firm and investment characteristics, and investment, year, and industry fixed effects. For each regression in Panel B we report only the coefficient on the relevant covenant. Firm characteristics include: profitability, size, leverage, industry, bank relationships and board seats (during). Investment type is: early, expansion, buyout, turnaround. We also include a dummy for un-exited deals. All regressions have 782 observations. Standard errors clustered at the management company level are in parenthesis. ***, **, and * indicate significance at the 1,5 , and $10 \%$ levels. 
Table 7

Performance Regressions Adjusted for Selection Bias

\begin{tabular}{|c|c|c|c|c|c|c|c|c|}
\hline & \multicolumn{8}{|c|}{ Panel A: Coefficients for Covenant Heavy } \\
\hline & (1a) & (1b) & $(2 a)$ & (2b) & $(3 a)$ & $(3 b)$ & (4a) & $(4 b)$ \\
\hline & IRR & IRR & $\Delta$ Sales & $\Delta$ Sales & $\triangle \mathrm{ROA}$ & $\triangle \mathrm{ROA}$ & $\triangle \mathrm{ROE}$ & $\triangle \mathrm{ROE}$ \\
\hline Profitability & $\begin{array}{c}0.114 \\
(0.097)\end{array}$ & $\begin{array}{c}0.033 \\
(0.051)\end{array}$ & $\begin{array}{c}0.034 \\
(0.033)\end{array}$ & $\begin{array}{c}0.042 \\
(0.026)\end{array}$ & $\begin{array}{c}0.039 \\
(0.033)\end{array}$ & $\begin{array}{c}0.032 \\
(0.027)\end{array}$ & $\begin{array}{c}0.043 \\
(0.122)\end{array}$ & $\begin{array}{c}0.051 \\
(0.115)\end{array}$ \\
\hline Size & $\begin{array}{c}0.029 * * \\
(0.012)\end{array}$ & $\begin{array}{c}0.031 * * * \\
(0.011)\end{array}$ & $\begin{array}{c}0.012 * * * \\
(0.004)\end{array}$ & $\begin{array}{c}0.019 * * * \\
(0.005)\end{array}$ & $\begin{array}{c}0.009 * * \\
(0.004)\end{array}$ & $\begin{array}{c}0.021 * * * \\
(0.006)\end{array}$ & $\begin{array}{l}0.028 * \\
(0.015)\end{array}$ & $\begin{array}{c}0.074 * * * \\
(0.024)\end{array}$ \\
\hline Leverage & $\begin{array}{c}0.037 \\
(0.338)\end{array}$ & $\begin{array}{c}-0.550 * * \\
(0.249)\end{array}$ & $\begin{array}{c}0.071 \\
(0.117)\end{array}$ & $\begin{array}{c}-0.272 * * \\
(0.125)\end{array}$ & $\begin{array}{c}0.111 \\
(0.114)\end{array}$ & $\begin{array}{c}-0.182 \\
(0.129)\end{array}$ & $\begin{array}{c}0.280 \\
(0.428)\end{array}$ & $\begin{array}{c}-0.646 \\
(0.557)\end{array}$ \\
\hline Bank Relationship & $\begin{array}{c}-0.045^{*} \\
(0.024)\end{array}$ & $\begin{array}{l}0.035^{*} \\
(0.021)\end{array}$ & $\begin{array}{c}-0.016 * \\
(0.008)\end{array}$ & $\begin{array}{l}-0.003 \\
(0.011)\end{array}$ & $\begin{array}{c}-0.013 \\
(0.008)\end{array}$ & $\begin{array}{l}-0.005 \\
(0.011)\end{array}$ & $\begin{array}{c}-0.038 \\
(0.031)\end{array}$ & $\begin{array}{c}-0.036 \\
(0.048)\end{array}$ \\
\hline$\%$ Shares & $\begin{array}{c}-0.455 * * \\
(0.197)\end{array}$ & $\begin{array}{c}0.201 \\
(0.162)\end{array}$ & $\begin{array}{c}-0.161 * * \\
(0.068)\end{array}$ & $\begin{array}{l}-0.127 \\
(0.082)\end{array}$ & $\begin{array}{c}-0.180 * * * \\
(0.066)\end{array}$ & $\begin{array}{c}-0.094 \\
(0.084)\end{array}$ & $\begin{array}{c}-0.748^{* * *} \\
(0.249)\end{array}$ & $\begin{array}{c}-0.086 \\
(0.363)\end{array}$ \\
\hline Board Seats (During) & $\begin{array}{c}-0.004 \\
(0.004)\end{array}$ & $\begin{array}{c}-0.007 * \\
(0.004)\end{array}$ & $\begin{array}{l}-0.002 \\
(0.001)\end{array}$ & $\begin{array}{c}0.003 \\
(0.002)\end{array}$ & $\begin{array}{c}-0.005 * * * \\
(0.001)\end{array}$ & $\begin{array}{l}-0.001 \\
(0.002)\end{array}$ & $\begin{array}{c}-0.013 * * \\
(0.005)\end{array}$ & $\begin{array}{l}-0.005 \\
(0.008)\end{array}$ \\
\hline Inverse Mills Ratio & $\begin{array}{c}0.251 * * * \\
(0.092)\end{array}$ & $\begin{array}{c}0.182 * * \\
(0.073)\end{array}$ & $\begin{array}{c}0.124 * * * \\
(0.032)\end{array}$ & $\begin{array}{c}0.231 * * * \\
(0.037)\end{array}$ & $\begin{array}{c}0.090 * * * \\
(0.031)\end{array}$ & $\begin{array}{c}0.204 * * * \\
(0.038)\end{array}$ & $\begin{array}{c}0.275^{* *} \\
(0.116)\end{array}$ & $\begin{array}{c}0.756^{* * *} \\
(0.163)\end{array}$ \\
\hline Observations & 453 & 370 & 453 & 370 & 453 & 370 & 453 & 370 \\
\hline Adjusted R-squared & 0.066 & 0.267 & 0.115 & 0.436 & 0.117 & 0.398 & 0.076 & 0.366 \\
\hline \multicolumn{9}{|c|}{ Panel B: Inverse Mills Ratios for Incentive Covenants } \\
\hline Inverse Mills Ratio & $\begin{array}{l}0.194 * \\
(0.104) \\
\end{array}$ & $\begin{array}{c}0.371 * \\
(0.195) \\
\end{array}$ & $\begin{array}{c}0.049 * \\
(0.026) \\
\end{array}$ & $\begin{array}{c}0.674 \\
(1.249) \\
\end{array}$ & $\begin{array}{c}0.263 * * \\
(0.104) \\
\end{array}$ & $\begin{array}{l}0.074 * \\
(0.042)\end{array}$ & $\begin{array}{l}0.142 * \\
(0.075)\end{array}$ & $\begin{array}{c}0.358 * * \\
(0.156) \\
\end{array}$ \\
\hline \multicolumn{9}{|c|}{ Panel C: Inverse Mills Ratios for Default Covenants } \\
\hline Inverse Mills Ratio & $\begin{array}{c}0.021 \\
(0.133) \\
\end{array}$ & $\begin{array}{c}0.161 \\
(0.163) \\
\end{array}$ & $\begin{array}{c}0.064 \\
(0.043) \\
\end{array}$ & $\begin{array}{c}0.161 \\
(0.112) \\
\end{array}$ & $\begin{array}{c}0.044 \\
(0.042) \\
\end{array}$ & $\begin{array}{c}0.208^{*} \\
(0.119) \\
\end{array}$ & $\begin{array}{c}0.096 \\
(0.142) \\
\end{array}$ & $\begin{array}{c}0.888 \\
(0.561) \\
\end{array}$ \\
\hline \multicolumn{9}{|c|}{ Panel D: Inverse Mills Ratios for Protection Covenants } \\
\hline Inverse Mills Ratio & $\begin{array}{c}0.109 * * * \\
(0.039)\end{array}$ & $\begin{array}{c}0.006 \\
(0.038)\end{array}$ & $\begin{array}{c}0.323 * * \\
(0.134)\end{array}$ & $\begin{array}{c}0.362 * * \\
(0.179) \\
\end{array}$ & $\begin{array}{c}0.074 * \\
(0.042) \\
\end{array}$ & $\begin{array}{c}0.104 * * * \\
(0.038)\end{array}$ & $\begin{array}{c}0.226 * * * \\
(0.039)\end{array}$ & $\begin{array}{c}0.104 * * \\
(0.046) \\
\end{array}$ \\
\hline
\end{tabular}

This table reports the estimation of Equations 2 and 3 with the dependent variable changing across columns: IRR in columns 1a and 1b, Change in Sales in columns $2 \mathrm{a}$ and 2b, Change in ROA in columns $3 \mathrm{a}$ and $3 \mathrm{~b}$, and Change in ROE in Columns $4 \mathrm{a}$ and 4b. Coefficients in columns 1a, 2a, $3 \mathrm{a}$ and $4 \mathrm{a}$ are for Equation $3\left(I_{i}=0\right)$, while in columns $1 \mathrm{~b}, 2 \mathrm{~b}, 3 \mathrm{~b}$ and $4 \mathrm{~b}$ we estimate Equation $2\left(I_{i}=1\right)$. The criterion functions $I_{i}$ refer to the inclusion/exclusion of different types of covenants in the deals: Covenant Heavy in Panel A, Incentive Covenants in Panel B, Default Covenants in Panel C, and Protection Covenants in Panel D. More precisely, Covenant Heavy is a dummy variable that takes value one if the number of covenants employed in a deal is above median. Incentive, Default, and Protection Covenants are dummies for inclusion of incentive, default, or protection covenants in the deal, respectively. We control for firm characteristics, investment type and outcome (exited/unexited); year and industry fixed effects. We also include four instruments all computed over the six months preceding the investment: public market returns, average industry ROE, ratio of IPOs to newly created firms, and average number of covenants in previous deals. We also report the Wald test on the significance of the instruments. $* * *, * *$, and * indicate significance at the 1,5 , and $10 \%$ levels. 
Table 8

The Effect of Covenants on Returns: Estimation of $\gamma$

\begin{tabular}{|c|c|c|c|c|}
\hline \multirow[b]{3}{*}{ Outcome variable in $2^{\text {nd }}$ stage } & \multicolumn{4}{|c|}{ Selection variable in $1^{\text {st }}$ stage } \\
\hline & $(1)$ & $(2)$ & $(3)$ & $(4)$ \\
\hline & $\begin{array}{c}\text { Covenant } \\
\text { Heavy }\end{array}$ & $\begin{array}{l}\text { Incentive } \\
\text { Covenants }\end{array}$ & $\begin{array}{c}\text { Default } \\
\text { Covenants }\end{array}$ & $\begin{array}{l}\text { Protection } \\
\text { Covenants }\end{array}$ \\
\hline \multirow[t]{2}{*}{ IRR } & -0.050 & -0.150 & -0.028 & -0.016 \\
\hline & $(0.156)$ & $(0.107)$ & $(0.037)$ & $(0.151)$ \\
\hline \multirow[t]{2}{*}{$\Delta$ Sales } & $0.895 * * *$ & $0.359 * *$ & -0.044 & 0.044 \\
\hline & $(0.317)$ & $(0.178)$ & $(0.123)$ & $(0.340)$ \\
\hline \multirow[t]{2}{*}{$\triangle \mathrm{ROA}$} & $0.807 * * *$ & $0.333^{* *}$ & -0.155 & -0.242 \\
\hline & $(0.321)$ & $(0.190)$ & $(0.147)$ & $(0.510)$ \\
\hline \multirow[t]{2}{*}{$\triangle \mathrm{ROE}$} & $0.140 * *$ & 0.007 & -0.048 & -0.133 \\
\hline & $(0.082)$ & $(0.054)$ & $(0.030)$ & $(0.116)$ \\
\hline
\end{tabular}

This table contains estimated coefficients $\gamma$ for the difference in returns $\left(\mathrm{y}_{1}-\mathrm{y}_{2}\right)$ in Equations (2)-(3), as obtained through the three-stage procedure described in Lee (1978) and Goyal (2005). ***,**, and * indicate significance at the 1,5 , and $10 \%$ levels.

Table 9

Inside Directors

\begin{tabular}{|c|c|c|c|c|c|c|}
\hline \multirow[b]{4}{*}{ Outcome variable in $2^{\text {nd }}$ stage } & \multicolumn{6}{|c|}{ Measures of Inside Directors } \\
\hline & $(1)$ & $(2)$ & (3) & $(4)$ & $(5)$ & $(6)$ \\
\hline & \multicolumn{2}{|c|}{$\begin{array}{l}\text { Board Seats Before the } \\
\text { Investment }\end{array}$} & \multicolumn{2}{|c|}{ Employee of the Fund } & \multicolumn{2}{|c|}{ No Match of Duration } \\
\hline & $\begin{array}{c}\mathrm{Eq}(3) \\
I_{i}=0\end{array}$ & $\begin{array}{c}\mathrm{Eq}(2) \\
I_{i}=1\end{array}$ & $\begin{array}{c}\mathrm{Eq}(3) \\
I_{i}=0\end{array}$ & $\begin{array}{c}\text { Eq (2) } \\
I_{i}=1 \\
\end{array}$ & $\begin{array}{c}\text { Eq (3) } \\
I_{i}=0\end{array}$ & $\begin{array}{c}\text { Eq (2) } \\
I_{i}=1\end{array}$ \\
\hline IRR & $\begin{array}{c}0.000 \\
(0.003)\end{array}$ & $\begin{array}{l}-0.007^{*} \\
(0.004)\end{array}$ & $\begin{array}{c}-0.148 * * * \\
(0.052)\end{array}$ & $\begin{array}{c}-0.193 * * * \\
(0.069)\end{array}$ & $\begin{array}{l}-0.120 * * \\
(0.051)\end{array}$ & $\begin{array}{c}-0.176 * * * \\
(0.067)\end{array}$ \\
\hline$\Delta$ Sales & $\begin{array}{c}-0.186 * * * \\
(0.025)\end{array}$ & $\begin{array}{c}-0.090 * * * \\
(0.024)\end{array}$ & $\begin{array}{c}-0.180 * * * \\
(0.026)\end{array}$ & $\begin{array}{c}-0.088 * * * \\
(0.024)\end{array}$ & $\begin{array}{c}-0.171 * * * \\
(0.025)\end{array}$ & $\begin{array}{c}-0.079 * * * \\
(0.023)\end{array}$ \\
\hline$\triangle \mathrm{ROA}$ & $\begin{array}{c}-0.165 * * * \\
(0.026)\end{array}$ & $\begin{array}{c}-0.062 * * * \\
(0.023)\end{array}$ & $\begin{array}{c}-0.162 * * * \\
(0.027)\end{array}$ & $\begin{array}{c}-0.058 * * \\
(0.023)\end{array}$ & $\begin{array}{c}-0.156^{* * *} \\
(0.026)\end{array}$ & $\begin{array}{c}-0.050 * * \\
(0.023)\end{array}$ \\
\hline$\Delta \mathrm{ROE}$ & $\begin{array}{c}-0.633 * * * \\
(0.113)\end{array}$ & $\begin{array}{l}-0.191 * * \\
(0.087)\end{array}$ & $\begin{array}{c}-0.650 * * * \\
(0.115)\end{array}$ & $\begin{array}{l}-0.181 * * \\
(0.088)\end{array}$ & $\begin{array}{c}-0.634 * * * \\
(0.110)\end{array}$ & $\begin{array}{l}-0.151 * \\
(0.085)\end{array}$ \\
\hline
\end{tabular}

This table reports the estimated coefficients for inside director, computed in Equations (2) and (3) after correcting for the selection bias in the use of covenants. The selection variable in the first stage is the covenant heavy dummy for all regressions. $* * *, * *$, and $*$ indicate significance at the 1,5 , and $10 \%$ levels respectively. 